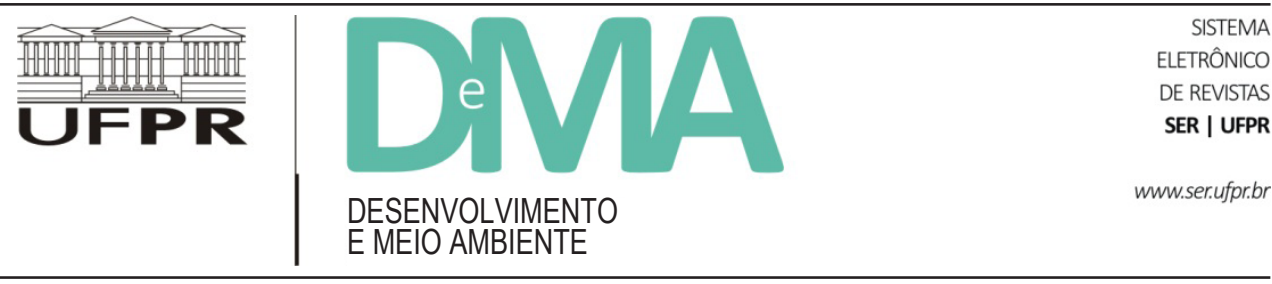

\title{
A vedação de tratamento cruel contra os animais versus direitos culturais: breve análise da ótica do Supremo Tribunal Federal no julgamento do Recurso Extraordinário no 153531/SC
}

\section{Prohibition Against Cruel Treatment of Animals versus Cultural Rights: Brief Analysis of the View of the Supreme Court in the Judgment of the Extraordinary Appeal no 153531/SC}

\author{
Nicanor Henrique Netto ARMANDO ${ }^{1}$ \\ ${ }^{1}$ Mestre em Direito Ambiental e Desenvolvimento Sustentável (ESDHC). Aluno do programa de doutorado em Direito processual da Pontifícia \\ Universidade Católica de Minas Gerais (PUC Minas). E-mail: henrique.armando@yahoo.com.br
}

Artigo: Recebido em: 28 de junho de 2013; Versão final aceita em: 21 de março de 2014.

RESUMO O presente artigo desenvolveu uma breve análise acerca da atuação do Supremo Tribunal Federal no julgamento no Recurso Extraordinário $\mathrm{n}^{\circ} 153531 / \mathrm{SC}$, que buscou dirimir a controvérsia originada pela realização de uma manifestação cultural realizada no Estado de Santa Catarina (farra do boi), que suscitava a colisão entre a proteção do direito à cultura, de um lado, e a proteção dos animais, de outro. Seu objetivo foi investigar se, à luz do aludido julgamento, o Supremo Tribunal Federal chega a identificar um estatuto jurídico de proteção dos animais na ordem jurídica constitucional brasileira e determinar qual seria o sentido e o alcance atribuídos a essa proteção no tocante ao significado constitucional da proibição da crueldade. A pesquisa investigou qual a interpretação que o STF atribui ao conteúdo da norma de proteção, vale dizer, qual entendimento a suprema corte empresta ao objetivo proposto por essa norma e qual o sentido constitucional da prática proibida (crueldade). A conclusão do trabalho aponta que a decisão da suprema corte, ao assentar a superioridade da proteção dos animais sobre uma manifestação cultural quando esta importar na prática de crueldade contra aqueles, corrobora o entendimento de que o inciso VII, $\S 1^{\circ}$ do art. 225, da Constituição Federal, rompendo com perspectiva antropocêntrica, de inspiração kantiana, consagra a concepção biocêntrica que, ao contrário da primeira, atribui aos animais valor intrínseco e dignidade próprios, independentemente de sua utilidade para o alcance dos fins humanos. Mediante o cotejamento de trechos do acórdão com exposições doutrinárias a respeito, vislumbrou-se, ainda, em certa medida, a atribuição de uma dimensão ecológica à dignidade humana e a proclamação do meio ambiente ecologicamente equilibrado como direito humano e fundamental.

Palavras-chave: animais; crueldade; proteção jurídica; paradigma biocêntrico; direito cultural. 
ABSTRACT This paper developed a brief analysis on the performance of the Supreme Court judgment in the Extraordinary Appeal No. 153531/SC that sought to settle the dispute arising from the realization of a cultural manifestation allegedly performed in the State of Santa Catarina (binge ox), which raised the collision between the protection of the right to culture, on the one hand, and protection of animals on the other. Our goal was to investigate whether, in the light of the aforementioned judgment, the Supreme Court comes to identify a legal protection of animals in Brazilian constitutional law and determine what would be the meaning or scope attributed to this protection regarding the meaning of the constitutional prohibition of cruelty. The research investigated what interpretation the Supreme Court gives to the content of protection standard, that is, the understanding that the Supreme Court has about the objective proposed by this rule and what is the constitutional sense of the prohibited practice (cruelty). The conclusion of the paper points out that the decision of the supreme court of settling the superiority of animal protection over a cultural event when the practice of cruelty against those mattered supports the view of the section VII, $\S 1$ of Art. 225 of the Federal Constitution. Breaking anthropocentric perspective of Kantian inspiration, this enshrines the biocentric view that, unlike the first one, gives the animals their own intrinsic value and dignity, regardless of their usefulness to the achievement of human ends. Through the comparison of sequences of the judgment with doctrinal expositions we noticed, even to some extent, the assignment of an ecological dimension to human dignity and the proclamation of an ecologically balanced environment as a fundamental human right.

Keywords: animals; cruelty; legal protection; biocentric paradigm; cultural right.

\section{Introdução}

No presente trabalho, pretende-se implementar uma análise da atuação da suprema corte do país - a primeira, diga-se de passagem - no tocante à resolução de casos envolvendo a colisão entre a proteção do direito à cultura, de um lado, e a proteção dos animais, de outro.

Procurar-se-á investigar se a jurisprudência do Supremo Tribunal Federal (STF) chega a identificar um estatuto jurídico de proteção dos animais na ordem jurídica constitucional brasileira e determinar: qual é o sentido e o alcance atribuídos a essa proteção no tocante ao significado constitucional da proibição da crueldade? Para tal desiderato, mediante a identificação da ratio decidendi empregada pelo STF para fundamentar a decisão do acórdão paradigma, buscar-se-á determinar: qual a interpretação atribuída ao conteúdo da norma de proteção, vale dizer, qual entendimento a suprema corte empresta ao objetivo proposto por essa norma e qual o sentido constitucional da prática proibida (crueldade)?

Para tanto, tomar-se-á como paradigmático o acórdão prolatado no Recurso Extraordinário no 153531/SC, cujo questionamento era se determinada manifestação pretensamente cultural realizada no Estado de Santa Catarina (Farra do $\mathrm{Boi}^{2}$ ) poderia ser abrangida pelo

1 “A farra do boi está presente em solo catarinense há, pelo menos, dois séculos. Sua origem remonta ao povoamento da costa litorânea do Estado
de Santa Catarina pelos luso-brasileiros a partir da segunda metade do século XVII e a sua ocupação efetiva pelos 'casais açorianos' em meados
do século XVIII. Neste período, as touradas ocorriam praticamente em todo o Arquipélago de Açores. Em virtude de sua origem pecuarista,
os açorianos sempre estiveram familiarizados com o gado bravio, fato que predispôs a expansão das tauromaquias pelas diversas ilhas que
compõem o Arquipélago. Rituais açorianos - como a 'espera do gado', onde a população espera, num local previamente reservado para o rito,
a soltura de vários bois, que passam a ser objeto de várias 'brincadeiras'; a 'tourada a corda', na qual o animal, amarrado pelo pescoço por uma
corda, passa a ser objeto de tauromaquia por parte da população; e a 'festa brava', em que o gado bravio sofre perseguições e é posteriormente
sacrificado - podem ser identificados como antecedentes diretos da farra do boi.”
Consta que a partir de 1748 , época em que as touradas populares eram bastante corriqueiras na região, os açorianos começaram a imigrar para
Santa Catarina. "[...] Apesar da sua antiguidade, a farra do boi nunca teve grande visibilidade, realizando-se basicamente em áreas de campo,
pasto ou praias e ficando restrita às comunidades nativas. Contudo, ocorria em quase toda a extensão da ilha de Santa Catarina, exceto nas áreas
propriamente urbanas, acontecendo, ao todo, em 23 municípios" (Bahia, 2008, p. 404-405).
A farra do boi pode ser descrita da seguinte forma: "um boi-de-campo (ou vários bois), necessariamente bravo, arisco e corredor, é escolhido e
comprado para um grupo de farristas, mediante uma lista de sócios. A escolha do melhor animal subentende algumas horas de intensas nego- 
manto da proteção do patrimônio cultural brasileiro, conferida pelo art. 216 da Constituição Federal, ou se tal prática importaria em violação da vedação da prática de crueldade contra os animais que, da mesma forma, goza de estatura constitucional.

A ementa do aludido acórdão acha-se assim vazada:

COSTUME - MANIFESTAÇÃO CULTURAL - ESTÍMULO - RAZOABILIDADE - PRESERVAÇAO DA FAUNA E DA FLORA - ANIMAIS - CRUELDADE. A obrigação de o Estado garantir a todos o pleno exercício de direitos culturais, incentivando a valorização e a difusão das manifestações, não prescinde da observância da norma do inciso VII do artigo 225 da Constituição Federal, no que veda prática que acabe por submeter os animais à crueldade. Procedimento discrepante da norma constitucional denominado "farra do boi". (Brasil, 1998b)

Conforme já enuncia e antecipa a própria ementa, o STF reconheceu que, ao lado da proteção de direitos culturais, a Constituição Federal também protege os animais contra a prática de crueldade.

O recurso extraordinário originou-se de ação civil pública que foi intentada no juízo de primeiro grau pelas recorrentes (associações ligadas à defesa dos animais) em face do Estado de Santa Catarina, tendo como escopo condenar a parte ré à obrigação de se fazer consistente na adoção de atos e medidas formais e práticas objetivando proibir a denominada "festa da farra do boi" e ou manifestações assemelhadas.

A causa petendi se embasava na norma descrita no art. 225, inciso VII, da Constituição Federal, a qual proíbe qualquer prática cujo efeito material seja a submissão de animais a crueldade.

Ao contestar a ação, o réu e ora recorrido, nas alegações de mérito, negou que a "Farra do Boi", mani- festação cultural bastante entranhada em significativas parcelas da sociedade, fosse uma prática intrinsecamente cruel ou violenta e que houvesse omissão do Poder Público estadual, que adotou várias iniciativas para coibir os excessos.

Ao julgar o feito, o juízo primevo, embora tenha tangenciado o mérito ao tecer considerações acerca da aludida manifestação folclórica, julgou as autoras carecedoras da ação por identificar a impossibilidade jurídica do pedido formulado.

Em sede de apelação, o Tribunal de Justiça, apesar de negar provimento ao recurso, reconhecendo o valor do pedido no domínio ético, entendeu que o dispositivo da sentença de primeiro grau deveria ser alterado porque, tendo o juiz se manifestado acerca do mérito, o caso era de improcedência do pedido e não de extinção do feito sem julgamento do mérito.

Verifica-se que o juiz inacolheu o pedido por situá-lo no âmbito da ética, o que lhe valeu a pecha de juridicamente impossível.

Já a corte estadual, embora corrigindo a errônea qualificação do pedido como juridicamente impossível, entendeu-o improcedente em razão da não configuração de prática cruel ou violenta, mas sim de uma manifestação cultural.

O relator, Min. Francisco Rezek, prefacialmente, muito bem obtemperou que, embora o dispositivo do inciso VII do art. 225 da Constituição Federal contenha a qualificativa "na forma da lei", ele é autoaplicável na medida em que dele se extrai claramente a norma que proíbe qualquer prática cujo efeito material seja a submissão de animais a crueldade, não carecendo da complementação de outra norma para impor ao poder público um comando no sentido de adotar, legislativa ou administrativamente, providências para lhe conferir efetividade.

Como observou o relator, o suposto caráter metajurídico que envolve a controvérsia em exame levou

ciações com os fazendeiros até chegar a um bom termo, i.é, o melhor preço para as partes e o boi mais bravo para os farristas. [...] Escolhido o boi, o animal é transportado para a comunidade e solto em locais previamente decididos pelos sócios. A soltada do boi reveste-se de uma euforia inigualável. São centenas de pessoas aguardando a chegada do animal, anunciada por foguetes e buzinas durante o trajeto. A partir daí, passa a ser objeto de brincadeiras - pegas, correrias, lides, procuras, ataques e fugas - em lugares os mais diversos: normalmente onde há mato, pastos, morros e praias; também se dá em áreas marcadas e cercadas (mangueirões); em bairros, praças e ruas centrais das cidades e vilarejos. Cria-se uma atmosfera imprevisível, pois a expectativa dos farristas é brincar com a fúria do boi. Atravessa-se a noite toda atrás do animal quando este não se perde no mato adentro [...]." (Lacerda apud Bahia, 2008, p. 408-409). 
o magistrado de primeiro grau a, equivocadamente, extinguir o feito sem julgamento de mérito por reputar o pedido juridicamente impossível.

Nada mais errado, frise-se, pois, apesar de a controvérsia suscitar inegável colisão de valores no âmbito do domínio ético, tais axiomas foram juridicizados e se acham expressamente positivados na Constituição Federal, passando a constituir princípios jurídicos com os quais, lamentavelmente, alguns operadores do direito não estão familiarizados em razão de ainda estarem arraigados a uma epistemologia positivista na abordagem do Direito.

\section{O reconhecimento da dignidade da vida não humana e dos animais}

Há uma passagem no acórdão em que o relator, embora não o tenha feito expressamente, sinaliza reconhecer dignidade e direitos próprios aos animais, dotando-os de valor intrínseco e não apenas utilitarista, superando a perspectiva antropocêntrica que é o apanágio da formulação Kantiana, segundo a qual os deveres para com a Natureza não passariam, na verdade, de um conjunto de deveres indiretos para com a própria humanidade.

De resto, com a negligência no que se refere à sensibilidade de animais anda-se meio caminho até a indiferença a quanto se faça a seres humanos. Essas duas formas de desídia são irmãs e quase sempre se reúnem, escalonadamente (Brasil, 1998b).

Tal entendimento sinaliza a promoção de uma ruptura com o conceito Kantiano de dignidade, de cariz antropocêntrico e individualista, e nos convida a ampliá-lo para além da vida humana, fazendo-o incidir sobre os animais não humanos e a todas as formas de vida de um modo em geral.

Pautados nesta perspectiva de matriz filosófica biocêntrica, Sarlet e Fensterseifer assinalam que

Em relação aos animais não humanos deve-se reformular o conceito de dignidade, objetivando o reconhecimento de um fim em si mesmo, ou seja, de um valor intrínseco conferido aos seres sensitivos não humanos, que passam a ter reconhecido o seu status moral e dividir com o ser humano a mesma comunidade moral. Tais considerações implicam o reconhecimento de deveres jurídicos a cargo dos seres humanos, tendo como beneficiários os animais não humanos e a vida em geral (Sarlet \& Fensterseifer, 2011, p. 42).

A propósito dessa referência a seres sensitivos levada a efeito pelos autores acima, para Peter Singer (2002) a senciência é um dos atributos de que são dotados os animais para que se reputem dignos do mesmo tratamento dispensado aos seres humanos. Para ele, sendo os animais seres dotados de sensibilidade e consciência, devem ser tratados com o mesmo respeito com que são tratados os seres humanos. O princípio da igual consideração de interesses deve ser aplicado sem distinguir o animal humano do não humano, devendo a capacidade de sofrer e de sentir ser levada em conta.

Singer, adotando um viés filosófico utilitarista, afirma que está na "capacidade de sofrimento a característica vital que concede a um ser o direito a uma consideração igual”. Segundo ele, se um ser (humano ou não humano) sofre, não haveria justificativa moral para recusar ter em conta esse sofrimento, da mesma forma que não haveria qualquer justificativa moral para considerar a dor (ou prazer) que os animais sentem como menos importante do que a mesma dor (ou prazer) sentida pelo ser humano (Singer apud Fensterseifer, 2008, p. 44).

A posse de senciência passa a figurar como um critério ético capaz de atribuir status moral aos animais, que passam a integrar a comunidade moral juntamente com os seres humanos, legitimando o reconhecimento de sua dignidade.

Feitos estes adendos, Sarlet e Fensterseifer continuam que

Pode-se falar também de limitações aos direitos fundamentais (dos seres humanos) com base no reconhecimento de interesses (jurídico-constitucionais) não humanos - se não direitos! - legitimados constitucionalmente, como é facilmente identificado na tutela dispensada à fauna e à flora através da vedação constitucional de "práticas que coloquem em risco sua função ecológica, provoquem a extinção de espécies ou submetam os 
animais a crueldade" (art. 225, § $1^{\circ}$, VII) (Sarlet \& Fensterseifer, 2011, p. 42).

No plano jurídico, os elementos éticos de tutela dos animais ganharam expressão em diversos documentos normativos.

Começando pelo Direito Internacional, tem-se que o Brasil é signatário da Declaração Universal dos Direitos dos Animais, editada pela Organização das Nações Unidas para a Educação, a Ciência e a Cultura (UNES$\mathrm{CO}$ ), e, como tal, assumiu o compromisso de proteger os animais em seu território. Esse diploma proclama que:

\section{Artigo $1^{\circ}$}

Todos os animais nascem iguais perante a vida e têm os mesmos direitos à existência.

Artigo $2^{\circ}$

1. Todo o animal tem o direito a ser respeitado.

2. O homem, como espécie animal, não pode exterminar os outros animais ou explorá-los violando esse direito; tem o dever de pôr os seus conhecimentos ao serviço dos animais.

3. Todo o animal tem o direito à atenção, aos cuidados e à proteção do homem.

Artigo $3^{\circ}$

1. Nenhum animal será submetido nem a maus-tratos nem a atos cruéis.

2. Se for necessário matar um animal, ele deve de ser morto instantaneamente, sem dor e de modo a não provocar-lhe angústia (UNESCO, 2013).

No que tange ao ordenamento jurídico interno, os animais, sejam eles silvestres, nativos, exóticos ou domesticados, ganharam expressa proteção jurídica no art. $225, \S 1^{\circ}$, inciso VII, da Constituição Federal, que dispõe:

Art. 225. Todos têm direito ao meio ambiente ecologicamente equilibrado, bem de uso comum do povo e essencial à sadia qualidade de vida, impondo-se ao Poder Público e à coletividade o dever de defendê-lo e preservá-lo para as presentes e futuras gerações.

$\S 1^{\circ}$ - Para assegurar a efetividade desse direito, incumbe ao Poder Público:

[...]

VII - proteger a fauna e a flora, vedadas, na forma da lei, as práticas que coloquem em risco sua fun- ção ecológica, provoquem a extinção de espécies ou submetam os animais a crueldade (Brasil, 1988, grifo nosso).

Verifica-se que, se a Constituição não chega a atribuir direitos aos animais, é inegável que, pelo menos, impõe ao Estado e à sociedade o dever de não praticar atos cruéis contra os animais.

Para Ayala (2011, p. 427), ao optar por situar a crueldade como objeto de censura constitucional, "a ordem jurídica brasileira não condiciona a adoção de medidas de proteção contra a crueldade à demonstração concreta do sofrimento das espécies da fauna".

A esse respeito, Ayala (2011, p. 427) sustenta que os animais são titulares de obrigações de proteção conferida pela ordem constitucional, que, mediante a interdição de práticas cruéis contra os animais, coloca uma obrigação que se dirige, de forma simétrica e com igual eficácia, aos agentes públicos e a toda a sociedade.

Segundo esse autor, o estabelecimento da proteção é realizado de maneira indireta, pois, ao se voltar apenas para a vedação de crueldade contra os animais sem fazer qualquer referência à palavra sofrimento, a ordem constitucional privilegia como foco de proteção a avaliação realizada diretamente sobre o comportamento do ofensor, vale dizer, sobre a ilicitude do comportamento externo (crueldade), desprezando qualquer avaliação sobre o bem-estar da vítima.

Em suma, a constituição prescinde da associação entre crueldade e sofrimento ao proibir práticas e comportamentos cruéis contra os animais.

No plano infraconstitucional, contudo, não se pode dizer o mesmo em ralação à forma com que essa proteção é estabelecida.

Conforme se depreende do $\S 1^{\circ}$ do art. 32 da Lei $n^{0}$ 9.605/1998, que criminalizou a conduta de praticar atos cruéis ou causar maus-tratos aos animais, ao contrário da metodologia adotada pela Constituição para estabelecer a adoção de medidas de proteção contra a crueldade de animais, os elementos constitutivos do referido tipo penal exigem a demonstração concreta do sofrimento dos animais, o que o torna uma norma de proibição que requer a produção de sofrimento, in verbis: 
Art. 32. Praticar ato de abuso, maus-tratos, ferir ou mutilar animais silvestres, domésticos ou domesticados, nativos ou exóticos:

Pena - detenção, de três meses a um ano, e multa.

$\S 1^{\circ}$ Incorre nas mesmas penas quem realiza experiência dolorosa ou cruel em animal vivo, ainda que para fins didáticos ou científicos, quando existirem recursos alternativos.

$\S 2^{\circ}$ A pena é aumentada de um sexto a um terço, se ocorre morte do animal (Brasil, 1998a, grifo nosso).

Essa última modalidade de proibição, contudo, é criticada por Ayala (2011, p. 427), pois, na sua concepção, enquanto a referência à crueldade pode ser objetivamente definida e caracterizada a partir de bases flexíveis e segundo um complexo conjunto valorativo, a referência a sofrimento tem conteúdo que evoca elementos de avaliação bastante mais limitados e restritivos, ainda que não se limite à dimensão física ou material.

Por não pressupor a identificação semântica entre as referências crueldade e sofrimento, o ordenamento jurídico pátrio, salvo a exceção acima, não condiciona a adoção de medidas de proteção contra a crueldade de animais à demonstração concreta de sofrimento das espécies da fauna, silvestre ou não (Ayala, 2011, p. 427).

Ao contrário, a proibição de crueldade justifica a adoção de medidas de proteção independentemente da demonstração objetiva de suplício ou sofrimento físico ou psíquico que tenha sido infligido ao animal, ou que o tenha exposto a situação de risco intolerável, sendo suficiente a afirmação do estado de reprovação e censura prática (Ayala, 2011, p. 427).

O Supremo, infelizmente, não chegou a enfrentar a questão sob o ângulo da Lei $n^{\circ} 9.605 / 1998$, porque, ao tempo da decisão em comento, ela ainda não havia sido editada. Isso lhe impossibilitou identificar por completo qual o alcance do significado da proibição de crueldade contra os animais em nosso ordenamento jurídico.

O STF, malgrado não tenha avançado a ponto de se posicionar sobre a atribuição de direitos aos animais ou outras formas de vida não humanas, rompeu com uma ética ambiental de perspectiva antropocêntrica e racionalista e reconheceu, neste caso, que a vida animal e não humana constitui um fim em si mesmo, atribuindo-lhe dignidade própria e lhe reconhecendo um valor intrínseco (Sarlet \& Fensterseifer, 2011, p. 241).
Todas as concepções (e a de Kant é provavelmente apenas a mais influente) que sustentam ser a dignidade atributo exclusivo da pessoa humana encontram-se, pelo menos em princípio, sujeitas à crítica de um excessivo antropocentrismo, notadamente, naquilo em que sustentam que a pessoa humana, em função de sua racionalidade, ocupa lugar superior e privilegiado em relação aos demais seres vivos. No entanto, para além de tal "compreensão especista", sempre haverá como sustentar a dignidade da própria vida de um modo geral, ainda mais numa época em que o reconhecimento da proteção do ambiente como valor ético-jurídico fundamental indicia que não mais está em causa apenas a vida humana, mas a preservação de todos os recursos naturais, incluindo todas as formas de vida existentes no planeta, ainda que se possa argumentar que tal proteção da vida em geral constitua, em última análise, exigência da vida humana e, acima de tudo, da vida humana com dignidade (Sarlet \& Fensterseifer, 2011, p. 63)

Contrariando a doutrina kantiana, cuja concepção individualista e antropocêntrica de dignidade coloca os animais como seres desprovidos de qualquer valor intrínseco, visualizando os deveres dos seres humanos para com os animais como um dever indireto para com a própria humanidade, Martha Nussbaum (apud Sarlet \& Fensterseifer, 2011, p. 63) defende uma ideia de justiça que transcenda tal perspectiva para reconhecer o valor intrínseco e a dignidade de animais não humanos. A ideia de dever moral de um tratamento não cruel dos animais, ressalta a autora, deve buscar o seu fundamento não mais na dignidade humana ou na compaixão humana, mas sim na própria dignidade inerente às existências dos animais não humanos.

\section{A dimensão ecológica da dignidade humana}

Voltando ao acórdão, o Min. Néri da Silveira pontifica que o exame da matéria posta em exame expõe duas vertentes de análise: de um lado, a garantia do pleno exercício dos direitos culturais e o acesso às fontes de cultura nacional assegurados pelo art. $215 \mathrm{da}$ Constituição Federal e, de outro, a vedação da prática de atos que submetam os animais a crueldade, estabelecida pelo art. 225. 
Observa-se que para o ministro, "há sem dúvida, nesses dispositivos do art. 225, nítida integração com os princípios e valores dos arts. $1^{\circ}$ e $3^{\circ}$ da Constituição, enquanto definem princípios fundamentais da República". Dentre tais princípios, sobressai-se o da dignidade da vida humana. Segundo o ministro, o dispositivo do art. 225 da Constituição Federal não pode ser compreendido dissociado dos valores e princípios maiores da carta maior.

Nessa ordem de ideias, em certa medida, é possível vislumbrar também nessa decisão histórica do Supremo Tribunal Federal a atribuição de uma dimensão ecológica da dignidade humana e a proclamação do meio ambiente ecologicamente equilibrado como direito humano e fundamental. terseifer,

Isso porque, conforme sustentam Sarlet e Fens-

Não se pode conceber a vida - com dignidade e saúde sem um ambiente natural saudável e equilibrado. A vida e a saúde humanas (ou como refere o caput do art. 225 da CF88, conjugando tais valores, a sadia qualidade de vida) só estão asseguradas no âmbito de determinados padrões ecológicos (Sarlet \& Fensterseifer, 2011, p. 39).

O Ministro continua que, no contraponto entre cultura e proteção dos animais, a primeira "pressupõe desenvolvimento que contribua para a realização da dignidade da pessoa humana e da cidadania e para a construção de uma sociedade livre, justa e solidária".

Ora, se o exercício dos direitos culturais consagrados constitucionalmente só se legitima na medida em que contribuam para a realização da dignidade da pessoa humana e esta, como dito, detém uma dimensão ecológica, é inolvidável que o direito à cultura deve ser compatibilizado com valores ecológicos, incluindo a proteção dos animais, que integram o conteúdo do princípio da dignidade da pessoa humana.

Como observa Tiago Fensterseifer (2008, p. 47), a própria vida guarda consigo o elemento dignidade, ainda mais quando a dependência existencial entre as espécies é cada vez mais corroborada pela ciência, consagrando a denominada teia da vida.

Identificando uma dimensão ecológica do princípio da dignidade da pessoa humana, esse autor assevera que "a qualidade ambiental, à luz da teoria constitucional dos direitos fundamentais, configura-se como elemento integrante do conteúdo normativo do princípio da dignidade da pessoa humana, especialmente em razão da sua imprescindibilidade à manutenção e à existência da vida", alçando o meio ambiente ecologicamente equilibrado à condição fundamental para o desenvolvimento humano.

Tal compreensão leva o autor a reformular o conceito Kantiano de dignidade, assentado na premissa que concebe o ser humano como um fim em si mesmo em suas relações sociais, para estendê-la às demais formas de vida em atenção aos valores ecológicos hauridos da ordem constitucional vigente.

Segundo ele, a Constituição Federal brasileira de 1988, incorporando os valores ecológicos em seu núcleo axiológico, consagra em seus arts. $5^{\circ}, \S 2^{\circ}$, e 255 o direito ao meio ambiente e lhe atribui o status de direito fundamental (formal e materialmente) tanto do indivíduo como da coletividade, como fruto de um processo de afirmação histórica dos direitos fundamentais e consolidação do Estado Socioambiental, em superação aos modelos de Estado Liberal e Social (Fensterseifer, 2008, p. 29).

Vê-se que, na dimensão ecológica da dignidade humana, esta é deslocada de uma concepção onde o ser humano é encarado isoladamente e opera-se a sua inserção em uma dimensão existencial mais ampla do ser humano, abarcando todas as demais manifestações que fundamentam a sua existência. Decorre daí a ideia de uma dimensão ecológica para o princípio da dignidade da pessoa humana (Fensterseifer, 2008, p. 34).

Para José Afonso da Silva, a dignidade da pessoa humana

É um valor supremo que atrai o conteúdo de todos os direitos fundamentais do homem, desde o direito à vida. Concebido como referência constitucional unificadora de todos os direitos fundamentais [observam Gomes Canotilho e Vital Moreira], o conceito de dignidade da pessoa humana obriga a uma densificação valorativa que tenha em conta o seu amplo sentido normativo-constitucional e não uma qualquer ideia apriorística do homem, não podendo reduzir-se o sentido da dignidade humana à defesa dos direitos pessoais tradicionais, esquecendo-a nos casos de direitos sociais, ou invocá-la para construir "teoria do núcleo da personalidade" individual, ignorando-a quando se trate de garantir as bases da existência humana (SILVA, 2000, p. 109). 
À luz do conceito jurídico de dignidade humana formulado por Sarlet (2005) $)^{3}$, Fensterseifer (2008, p. 35) propõe a sua adoção como "moldura conceitual-normativa" de modo a constituir o ponto de partida para a reformulação do aludido conceito em face dos novos desafios existenciais impostos pela degradação ambiental, consagrando-se a sua dimensão ecológica.

Em vista do conteúdo e da força normativa do princípio jurídico da dignidade da pessoa humana, projetam-se direitos tanto civis e políticos (natureza defensiva e negativa) como sociais (natureza prestacional e positiva), em que o Estado, fazendo valer a garantia constitucional do mínimo existencial, ministra as prestações materiais mínimas necessárias a uma vida em patamares dignos (Fensterseifer, 2008, p. 33).

Rompendo com o paradigma antropocêntrico de dignidade da pessoa humana que repousa em Kant, Fensterseifer (2008, p. 33) advoga a tese de uma concepção mais abrangente para tal princípio ao afirmar que ele, sendo fruto de um processo de construção histórica onde o seu conteúdo sobre alterações conforme as variantes culturais e existenciais de cada civilização, não deve ter o seu enfoque reduzido ao caráter biológico ou físico, podendo ser identificadas nele outras dimensões, como a ecológica.

Conforme o autor,

É importante conferir um destaque especial para as interações entre a dimensão natural ou biológica da dignidade humana e a sua dimensão ecológica (ou ambiental), a qual objetiva ampliar o conteúdo da dignidade para um padrão de qualidade e segurança ambiental (e não apenas de existência ou sobrevivência biológica), não obstante muitas vezes estar em jogo a própria existência natural da espécie humana nas questões postas pelos problemas ecológicos, e não apenas um nível de vida com qualidade ambiental (Fensterseifer, 2008, p. 35).

Ainda segundo ele, o equívoco cartesiano 4 que separa ser humano e natureza é realçado "pelo vínculo existencial elementar existente entre o ser humano e o ambiente natural", sendo insustentável pensar o humano sem relacioná-lo diretamente com o espaço ambiental e toda a cadeia de vida que fundamenta a sua existência.

A correlação entre direito à proteção ambiental e dignidade humana é realçada pela própria Declaração de Estocolmo que, conforme Eduardo Gomes e Bettina Bulzico (2010, p. 60), estabelece "o direito que toda a humanidade tem de desfrutar de condições de vida adequadas, mas que isso só pode ser realizado plenamente em um ambiente tal que lhe permita levar uma vida digna e gozar de bem-estar", ipsis litteris:

\begin{abstract}
Princípio $\mathrm{n}^{\circ} 1$ - $\mathrm{O}$ homem tem o direito fundamental à liberdade, à igualdade e a desfrutar de condições de vida adequadas em um meio ambiente de qualidade tal que lhe permita ter uma vida digna e gozar de bem-estar, e tem a solene obrigação de proteger e melhorar o meio para as presentes e futuras gerações [...] (grifo nosso)
\end{abstract}

Daniela Rodrigueiro Peres Fonseca identifica na relação entre o meio ambiente e a dignidade da pessoa humana uma conexão quase que indissociável, já que, segundo ela, pensar em meio ambiente exige duas considerações iniciais:

\footnotetext{
${ }^{2}$ Sarlet (2005, p. 62 apud Fensterseifer, 2008, p. 35) aduz que a dignidade humana "é a qualidade intrínseca e distintiva reconhecida em cada ser humano que o faz merecedor do mesmo respeito e consideração por parte do Estado e da comunidade, implicando, neste sentido, um complexo de direitos e deveres fundamentais que assegurem a pessoa tanto contra todo e qualquer ato de cunho degradante e desumano como venham a lhe garantir as condições existenciais mínimas para uma vida saudável, além de propiciar e promover sua participação ativa e corresponsável nos destinos da própria existência e da vida em comunhão com os demais seres humanos."

${ }^{3}$ Fensterseifer (2008, p. 37) assevera que, além de Kant, a filosofia de René Descartes também contribuiu para realçar o caráter eminentemente antropocêntrico da dignidade humana. Segundo Fensterseifer, "o filósofo francês defendia a ideia de que os animais poderiam ser equiparados a máquinas móveis ou autômatos, já que, diferentemente do homem, que é composto de corpo e alma (e, portanto, nunca poderia ser identificado como uma simples máquina), apenas possuiriam corpo. Ao afirmar que os animais não possuíam nenhuma razão e, portanto, tampouco valor intrínseco, Descartes abriu caminho para a separação entre ser humano e Natureza que até hoje marca a abordagem científica em quase todas as áreas do conhecimento, bem como para o processo de instrumentalização e apropriação da Natureza e dos recursos naturais, o que, em grande medida, tem nos conduzido ao atual estágio preocupante de degradação ambiental."
} 
A primeira a ser destacada é aquela que o eleva à categoria do primordial, do supremo direito coletivo; e isto em face do direito ambiental, em primeira análise, ter como bem, mediatamente tutelado, a própria vida humana. É que a ideia de meio ambiente, e aí se entenda aquele ecologicamente equilibrado, sadio, saudável (como determina a norma constitucional - artigo $225 \mathrm{CF} / 88$ ), torna-o realmente o maior dos direitos coletivos por estar intimamente relacionado à ideia de vida saudável, como sendo a única expressão da digna sobrevivência humana. Daí a segunda consideração, o meio ambiente é vida e vida sadia (Fonseca, 2000 apud Linhares \& Piemonte, 2010, p. 115).

Conforme assinala Regan, a ideia de direitos humanos (e fundamentais) ecológicos tem por objetivo

[...] reconciliar a base filosófica dos direitos humanos com os princípios ecológicos, conectando o valor intrínseco do ser humano com o valor intrínseco de outras espécies e do ambiente como um todo. A partir de tal compreensão, os direitos humanos (como, por exemplo, a dignidade humana, a liberdade, a propriedade e o desenvolvimento) precisam corresponder ao fato de que o indivíduo não opera somente num ambiente social, mas também num ambiente natural. Assim como o indivíduo também deve respeitar o valor intrínseco dos seres humanos, o indivíduo também deve respeitar o valor intrínseco de outros seres, como animais, plantas, ecossistemas, etc., (sic) consubstanciando a ideia de deveres ecológicos do ser humano para com as demais manifestações existenciais (Regan, 2006 apud Fensterseifer, 2008, p. 40, grifo no original).

\section{O resultado do julgamento e o método utilizado em sua resolução}

Retomando a questão que envolve o julgamento em análise, ou seja, se determinada manifestação afirmada pretensamente cultural, levada a efeito no Estado de Santa Catarina ("Farra do Boi"), poderia ser situada sob o pálio da proteção do patrimônio cultural brasileiro conferida pelo art. 216 da Constituição Federal ou se, ao revés, consistiria em prática sob vedação constitucional ante a configuração da crueldade rechaçada no art. 225, $\S 1^{\circ}$, inciso VII, in fine.
Apesar de na ocasião, conforme observa Ayala (2011, p. 429), o argumento de prática cultural protegida pela Constituição ter seduzido o Ministro Maurício Corrêa, a questão foi muito bem posicionada pelo Ministro Relator, Francisco Rezek, que, reconhecendo a evidente crueldade contra os animais associada à prática da "farra do boi", ponderou que

\begin{abstract}
Não posso ver como juridicamente correta a ideia de que em prática dessa natureza a Constituição não é alvejada. Não há aqui uma manifestação cultural com abusos avulsos; há uma prática abertamente violenta e cruel com os animais, e a Constituição não deseja isso. (Brasil, 1998b)
\end{abstract}

Ao se perguntar se, ao proibir o folclore regional denominado "Farra do Boi", o Estado, a pretexto de proteção dos animais, não estaria violando a disposição do art. 215 , caput e $\S 1^{\circ}$, da Constituição Federal, o Min. Maurício Corrêa adota posicionamento oposto ao do relator e propõe uma solução intermediária, por considerar que, se por um lado, a Constituição Federal veda a submissão dos animais a crueldade, de outro, ela impõe a proteção das manifestações da cultura popular ao Estado, o qual, no caso em exame, deveria apenas adotar medidas mitigadoras para evitar a violência e maus-tratos contra os animais ao invés de proibir a prática em si.

Conforme o ministro Marco Aurélio, a prática, ante os abusos e ares de crueldade com que é praticada em relação aos animais, atrai a incidência do disposto no inciso VII do art. 225 da Constituição Federal e que a manifestação cultural ali empreendida não merece o agasalho da Constituição Federal.

O relator considera que a "farra do boi" praticada no Estado de Santa Catarina, apesar de constituir uma inegável forma de manifestação cultural, pelo fato de implicar a prática de atos abertamente violentos e cruéis para com animais, que são rechaçados pela Constituição Federal, acabam desnaturando-a como manifestação cultural. Estes, segundo ele,

seriam as práticas existentes em outras partes do país, que também envolvem bois submetidos à farra do público, mas de pano, de madeira, de "papier mâché"; não seres vivos, dotados de sensibilidade e preservados 
pela Constituição da República contra esse gênero de comportamento. (Brasil, 1998b)

Nesse trecho do acórdão, se nos afigura o esboço de um método argumentativo lançado numa tentativa de conciliar a garantia da manifestação cultural com a proteção dos animais na perspectiva do postulado da proporcionalidade, em que a utilização de animais vivos e reais nestas práticas, apesar de ser adequada para viabilizar o exercício da manifestação cultural, não seria necessária na medida em que poderia ser substituída pela utilização figurativa de bois artificiais.

Mas, apesar de assentar a superioridade da proteção dos animais sobre uma manifestação cultural quando esta importar na prática de crueldade contra os animais, o tribunal não se manifestou quanto ao método argumentativo que os ministros adotaram para realizar a ponderação entre os princípios constitucionais em conflito. O STF não ofertou à testificação difusa das pessoas alcançadas pelo provimento judicial a racionalidade que orientou sua decisão.

A despeito dessa sinalização do relator, outra crítica que se coloca é que o STF, ao invés de ter adotado o radicalismo de proibir a "Farra do Boi", poderia ter contemporizado com a medida e, à luz do postulado da proporcionalidade, adotado um posicionamento em que a prática cultural seria admitida, mas mediante a adoção de medidas mitigadoras dos atos configuradores de crueldade contra os animais. Uma providência nesse sentido seria a estipulação legal de parâmetros e procedimentos para que ocorresse a morte humanitária dos animais empregados na prática cultural ou mesmo a substituição dos animais de verdade por simulacros confeccionados em madeira ou qualquer outro material que lhe emprestasse o máximo de similitude com os seres reais.

A propósito, Ayala (2011), ao afirmar que a vedação constitucional da prática de comportamentos cruéis também tem como fundamento a afirmação de uma situação de risco não provado cientificamente, pressupõe o princípio da precaução como um componente de tal proibição. Contudo, ele destaca que essa reprovação do risco dependerá do ingrediente cultural a ela associado. Isso, segundo ele, coloca em entrechoque o princípio da precaução com o elemento cultural subjacente, o qual, em ultima análise, é que determinará os valores e práticas culturais que devem ou não ser protegidos.

Tais dificuldades relacionadas ao estabelecimento de consensos sobre as manifestações culturais que podem ser protegidas por determinada ordem jurídica, segundo ele, colocam como parâmetro necessário à aplicação do princípio da precaução a realização de julgamentos de proporcionalidade nos processos de tomada de decisões sobre a medida precaucional a ser aplicada no caso concreto, observando-se a necessidade, adequação e suficiência.

Conforme observa Carolina Medeiros Bahia (2008, p. 420-421),

$\mathrm{O}$ aresto parece acolher como premissa básica o princípio da interpretação mais favorável aos animais. Contudo, é óbvio que este princípio não representa, perante a liberdade de ação cultural, uma precedência absoluta. Assim, a ausência de um balanceamento explícito entre os direitos em conflito levou o relator a infravalorizar os argumentos da parte recorrida, que se baseavam na ideia de que a farra do boi constitui uma manifestação cultural tutelada constitucionalmente.

Nota-se que apesar da ementa fazer referência ao princípio da razoabilidade, o voto do ministro Rezek não inclui a ponderação dos princípios envolvidos na farra do boi. Ao contrário disso, o relator chega a negar o caráter de manifestação cultural da farra do boi, afirmando que: "não há aqui uma manifestação cultural com abusos avulsos; há prática abertamente violenta e cruel para com animais e a Constituição não deseja isso".

Ao encarar a questão dessa maneira, o ministro parece se filiar à teoria das limitações constitucionais imanentes, que seriam limitações aos direitos fundamentais, impostas pela própria Constituição.

Dessa forma, ao enxergar a proibição dos atos de maus-tratos contra os animais como limite constitucional à liberdade de ação cultural, o ministro termina por determinar, no plano abstrato, uma hierarquia entre estes dois valores.

O problema oferecido por esta escolha é que este tipo de esquema metódico que se baseia na distinção entre direitos hierarquicamente superiores e hierarquicamente inferiores passa contemporaneamente por um forte questionamento. Diante dessa crise de método, a doutrina e a jurisprudência têm optado por modelos que privilegiam a ponderação de direitos, partindo da concepção de que, a priori, nenhum direito fundamental vale mais do que o outro. 
A composição de interesses e princípios tendencialmente colidentes, a exemplo da tentativa de conciliação de práticas culturais e representações valorativas de conteúdo plural em contraponto com a proteção da fauna e vedação de crueldade contra animais, evidencia o caráter conflituoso que caracteriza o Direito Ambiental e somente é passível de solução mediante a técnica da ponderação. Esta, entendida como a técnica jurídica de solução de conflitos normativos que envolvem valores em tensão, insuperáveis pelas formas hermenêuticas tracionais, tem ampla aplicabilidade no caso em exame.

Operacionalização dessa técnica ponderativa pode ocorrer mediante a aplicação do postulado da proporcionalidade.

Conforme o escólio de Feitoza Pacheco,

[...] a noção de proporcionalidade pode ser tratada, por enfoques diferentes, como princípio, postulado e regra. O princípio da proporcionalidade é um estado ideal de coisas a ser atingido, no qual todas as intervenções em direitos fundamentais somente seriam feitas se, previamente, tivessem sido examinadas e satisfeitas sua idoneidade, necessidade e proporcionalidade em sentido estrito. Em outras palavras, podemos pensar a proporcionalidade lato sensu e seus componentes idoneidade, necessidade e proporcionalidade stricto sensu como princípios cujo fim é promover um estado de coisas no qual todas as medidas legislativas, judiciais e administrativas sejam adequadas, necessárias e proporcionais stricto sensu relativamente aos direitos fundamentais. Para tanto, todos os meios necessários à realização desse estado ideal devem ser realizados, por exemplo, de lege ferenda, estabelecendo-se a exigência legal de sua demonstração prévia à realização de atos probatórios. O postulado da proporcionalidade é uma norma imediatamente metódica, que estrutura a interpretação e aplicação de enunciados normativos que impliquem intervenções em direitos fundamentais, mediante a exigência específica de relações e critérios determinados. Dessa forma, a proporcionalidade lato sensu impõe um determinado método argumentativo, consistente em se fundamentarem as intervenções em direitos fundamentais em três passos específicos sequenciais, que são os exames da idoneidade, da necessidade e da proporcionalidade stricto sensu (Feitoza Pacheco, 2007, p. 71-72, grifos no original).
Outro exemplo de incidência do postulado da proporcionalidade no Direito Ambiental pode ser encontrado no já falado $\S 1^{\circ}$ do art. 32 da Constituição Federal que, ao ampliar o tipo penal do caput para abarcar também a conduta de "quem realiza experiência dolorosa ou cruel em animal vivo, ainda que para fins didáticos ou científicos, quando existirem recursos alternativos", segundo Fensterseifer (2008, p. 51), revela a adoção de um critério de proporcionalidade (subcritério da necessidade) para justificar a utilização de animais em experiências científicas ou didáticas. Isso significa que aquela prática somente será juridicamente legítima se não houver outros meios alternativos para realização da experiência.

Nessa ordem de ideias, a "Farra do Boi", autêntica manifestação cultural, pode subsistir, desde que despojada de todos os seus aspectos cruéis ou reprováveis em face dos animais.

\section{Conclusão}

Apesar de não haver explicitado o método argumentativo que os ministros adotaram para realizar a ponderação entre os princípios e valores constitucionais em conflito no Recurso Extraordinário n. 153531/SC, o STF conheceu do recurso e lhe deu provimento para, nos termos do voto do relator, julgar a ação procedente e, em consequência, determinar que o Estado de Santa Catarina, em face do que dispõe o art. 225, $\S 1^{\circ}$, inciso VII, da Constituição Federal, adote as providências necessárias à não ocorrência de práticas que imponham crueldade aos animais empregados na "Farra do Boi".

Em sua decisão, o tribunal assentou a superioridade da proteção dos animais sobre uma manifestação cultural quando esta importar na prática de crueldade contra aqueles.

O STF, malgrado não tenha avançado a ponto de se posicionar sobre a atribuição de direitos aos animais ou outras formas de vida não humanas, rompeu com uma ética ambiental de perspectiva antropocêntrica e racionalista e reconheceu, neste caso, que a vida animal e não humana constitui um fim em si mesmo, atribuindo-lhe dignidade própria e lhe reconhecendo um valor intrínseco. 
Por não pressupor a identificação semântica entre as referências crueldade e sofrimento, a Constituição Federal não condiciona a adoção de medidas de proteção contra a crueldade de animais à demonstração concreta de sofrimento das espécies da fauna, silvestre ou não.

Exceção a essa regra que deflui da constituição é a figura delitiva do art. $32, \S 1^{\circ}$, da Lei 9.605/1988, que condiciona a adoção de medidas de proteção contra a crueldade de animais à demonstração concreta de sofrimento por eles.

O STF perdeu a oportunidade de assegurar a coexistência entre a manifestação cultural da "Farra do Boi" do Estado de Santa Catarina e a proteção dos animais mediante a adoção de práticas alternativas e responsáveis que assegurem o exercício dessa forma de expressão popular sem violar a proibição constitucional de crueldade e maus-tratos contra os animais.

A concepção Kantiana, que sustenta ser a dignidade atributo exclusivo da pessoa humana, não encontra respaldo no atual paradigma de Estado socioambiental de direito inaugurado com a Constituição Federal de 1988 e, pelo menos em tese, sujeita-se à crítica em razão de encerrar um excessivo antropocentrismo, notadamente quando sustenta que a pessoa humana, em função de sua racionalidade, ocupa lugar superior e privilegiado em relação aos demais seres vivos.

No entanto, abstraindo-se tal concepção, sempre será possível defender a ideia de que a dignidade vai além da vida humana, ainda mais numa época em que

\section{Referências}

Ayala, P. de A. O novo paradigma constitucional e a jurisprudência ambiental do Brasil. In: Canotilho, José Joaquim Gomes; Leite, José Rubens Morato (Org.). Direito Constitucional Ambiental Brasileiro. 4. ed. rev. São Paulo: Saraiva, 2011. p. 427-458.

Bahia, C. M. O caso da farra do boi no Estado de Santa Catarina: colisão de direitos fundamentais. In: Molinaro, Carlos Alberto et al. (Org.). A dignidade da vida e os direitos fundamentais para além dos humanos: uma discussão necessária. Belo Horizonte: Editora Fórum, 2008. p. 395-427. o reconhecimento da proteção do ambiente como valor ético-jurídico fundamental indicia que não mais está em causa apenas a vida humana, mas a preservação de todos os recursos naturais, incluindo todas as formas de vida existentes no planeta.

Contrariando a doutrina Kantiana, cuja concepção individualista e antropocêntrica de dignidade coloca os animais como seres desprovidos de qualquer valor intrínseco, visualizando os deveres dos seres humanos para com os animais como um dever indireto para com a própria humanidade, faz-se necessária uma ideia de justiça que transcenda a tal perspectiva, para reconhecer o valor intrínseco e a dignidade de animais não humanos.

Em suma, com fincas nessa moderna concepção biocêntrica da ética e do direito ambiental, em que os animais são dotados de dignidade e valores próprios, superando a perspectiva antropocêntrica que os reduzia a um mero instrumento de satisfação da dignidade humana e os sujeitava, inclusive, a alienações, por concebê-los como uma mera coisa objeto do direito de propriedade humana, o inciso VII, $\S 1^{\circ}$ do art. 225, da Constituição Federal respalda a referida concepção biocêntrica, conferindo uma tutela constitucional ao bem-estar dos animais.

A Constituição, se não chegou a atribuir direitos aos animais, pelo menos impôs ao Estado e à sociedade o dever de não praticar atos cruéis contra eles.

Nessa linha de ideias, a visão civilista que reputa aos animais a concepção de meros objetos do direito de propriedade já está ultrapassada.
Brasil. Constituição da República Federativa do Brasil. Diário Oficial da União, Brasília, 5 out. 1988. Disponível em: <http://www.planalto.gov.br/ccivil_03/constituição/ constiui\%C3\%A7ao.htm>. Acesso em 21 fev. 2013.

. Lei n. 9.605, de 12 de fevereiro de 1998. Dispõe sobre as sanções penais e administrativas derivadas de condutas e atividades lesivas ao meio ambiente, e dá outras providências. Diário Oficial da União, Brasília, 13 fev. 1998a. Disponível em: <http://www.planalto.gov.br/ccivil_03/leis/19605.htm>. Acesso em: 15 abr. 2013. 
Supremo Tribunal Federal. Recurso Extraordinário n. 153531/SC. Associação Amigos de Petrópolis, Patrimônio, Defesa dos Animais e Proteção da Ecologia (ANPADE) e Outros versus Estado de Santa Catarina. Relator: Ministro Marco Aurélio. Diário de Justiça da União, Brasília, 13 mar. 1998b.

Feitoza Pacheco, D. O princípio da proporcionalidade no Direito Processual Penal brasileiro. Rio de Janeiro, Lumen Juris, 2007.

Fensterseifer, T. Direitos fundamentais e proteção do ambiente: a dimensão ecológica da dignidade da pessoa humana no marco jurídico constitucional do estado socioambiental de direito. Porto Alegre: Livraria do Advogado Editora, 2008.

Gomes, E. B.; Bulzico, B. A. A. Soberania, cooperação e o direito humano ao meio ambiente. In: Sustentabilidade, desenvolvimento e democracia. Ijuí: Editora Unijuí, 2010. p. 49-70.
Linhares, M. T. M.; Piemonte, M. N. Meio ambiente e educação ambiental à luz do princípio da dignidade da pessoa humana. Revista Veredas do Direito, Belo Horizonte, 7(13/14), 101-124, jan./dez. 2010.

Sarlet, I. W.; Fensterseifer, T. Direito constitucional ambiental: estudo sobre a Constituição, os Direitos Fundamentais e a proteção do ambiente. São Paulo: Editora Revista dos Tribunais, 2011.

Silva, J. A. da. Curso de Direito Constitucional Positivo. 18. ed. rev. e atual. São Paulo: Malheiros Editores, 2000.

Singer, P. Ética prática. São Paulo: Martins Fontes, 2002.

UNESCO - Organização das Nações Unidas para a Educação, a Ciência e a Cultura. Declaração universal dos direitos dos animais. Proclamada em sessão realizada em Bruxelas em 27 jan. 1978. Disponível em: $<$ http://www.propp.ufms.br/index.ph p?section=institucional\&itemId=74>. Acesso em: 16 abr. 2013. 